\title{
New Synthetic Quinolines as Cathepsin K Inhibitors
}

\author{
Taynara L. Silva, ${ }^{\oplus a, b}$ Aloisio de A. Bartolomeu, ${ }^{\oplus a}$ Hugo C. R. de Jesus, ${ }^{\oplus a}$ Kleber T. de Oliveira, ${ }^{\oplus a}$ \\ João B. Fernandes, ${ }^{\oplus a}$ Dieter Brömme ${ }^{\oplus b}$ and Paulo C. Vieira ${ }^{\circledR} *, a, c$ \\ ${ }^{a}$ Departamento de Química, Universidade Federal de São Carlos, Washington Luís, km 235, \\ 13565-905 São Carlos-SP, Brazil \\ ${ }^{b}$ Faculty of Dentistry and UBC Center for Blood Research, 2350 Health Sciences Mall, \\ V6T1Z3 Vancouver, BC, Canada \\ ${ }^{c}$ Faculdade de Ciências Farmacêuticas de Ribeirão Preto, Universidade de São Paulo, \\ 14040-903 Ribeirão Preto-SP, Brazil
}

\begin{abstract}
Cathepsin $\mathrm{K}$ is a papain-like cysteine protease and is responsible for collagen degradation in bone tissue and thus represents an important target for the development of new therapies for treating diseases such as osteoporosis. Quinolines are an important class of heterocyclic molecular leads with a great pharmacological potential and represent a relevant scaffold to explore the chemical space of cathepsin $\mathrm{K}(\mathrm{CatK})$ inhibitors. This study presents the synthesis of nine 2,4-diphenylquinolines, including five phthalonitrile quinolines dyads, and the evaluation of their CatK inhibitory activity. Among the evaluated compounds, $\mathbf{4 b}$ was the most potent inhibitor with an $\mathrm{IC}_{50}$ (half-maximal inhibitory concentration) value of $1.55 \mu \mathrm{M}$ (against Z-Phe-Arg-MCA substrate) acting in an uncompetitive inhibition mode. Molecular docking studies provided important information on the interaction of the inhibitor with the enzyme showing that these quinoline derivatives can play an important role as CatK inhibitors.
\end{abstract}

Keywords: cathepsin K, cysteine protease, uncompetitive inhibitor, quinoline moieties

\section{Introduction}

Osteoporosis is a systemic disease that affects bone tissue. This is caused by the deregulation of the bone remodeling process and causes bone loss resulting in increased bone fragility and susceptibility for fractures. ${ }^{1}$ Bone remodeling is a dynamic process that involves specific cells. The mature tissue is reabsorbed by osteoclast action and the new bone tissue is formed by osteoblast action. This process replaces about $10 \%$ of the human skeleton each year. ${ }^{2}$ Until the middle of adult life these two mechanisms occur collectively and keep the bone mass stable. With advancing age, pathological problems of deregulation may occur in the remodeling process where bone resorption exceeds bone formation and thus results in the development of osteoporosis. ${ }^{3,4}$

Osteoporosis affects men and women, however, the loss of bone mass occurs in women about fifteen years earlier than in men due to hormonal changes during and

*e-mail: pcvieira@fcfrp.usp.br after menopause. ${ }^{5}$ It is estimated that half of women and a third of men will experience an osteoporotic fracture. ${ }^{1}$ Currently available antiresorptive therapies act on the bone remodeling process, however, they reduce resorption rates as well as bone formation rates. The study of new therapies show that through the inhibition of the enzyme cathepsin $\mathrm{K}$ (CatK) it is possible to have a selective reduction of bone resorption without interfering in its formation. So, treatments through pharmacological inhibition of cathepsin $\mathrm{K}$ increases bone mineral density. ${ }^{3,5,6}$

Cathepsin $\mathrm{K}$, a lysosomal cysteine protease is a member of the papain-like family (CA clan, $\mathrm{C} 1$ family) that is predominantly expressed in osteoclasts and plays a key role in the process of bone. These enzymes are involved in different physiological and pathological processes, being recognized for decades as potent targets for the development of treatment for several diseases. ${ }^{7-10}$

Predominantly expressed in osteoclasts, CatK plays a key role in the process of bone resorption. ${ }^{11}$ It is able to degrade collagen type I and type II which are the main components of bone and cartilage and cleave the triple 
helix of collagen at multiple sites. CatK has its high collagenolytic activity at the acidic $\mathrm{pH}$ which is also required to dissolve the calcium apatite component of bone. ${ }^{12-14}$

The inhibition of CatK reduces the bone resorption and can provide a promising approach for the treatment of disorders related to bones and cartilage, so this enzyme has become an attractive target in the search for antiresorptive therapies. Considerable efforts have been made in the search for highly potent and selective CatK inhibitors. ${ }^{15-18}$ Some inhibitors entered for clinical trials for the treatment of bone diseases, however, none have become a commercial drug. ${ }^{3,11}$

Nitrogen heterocycles have been previously shown to be active against cathepsins. ${ }^{19}$ Within this class of compounds the quinolines represent an important class of heterocyclic leads, since the quinoline scaffold is present in the structure of many pharmacologically active synthetic and natural compounds, which showed multiple biological effects, including antimalarial, anti-inflammatory, antifungal, antiprotozoal, anticancer. ${ }^{20-24}$

Based on our continuing interest in potential inhibitors (natural and/or synthetic) of cathepsins, ${ }^{19,25-30}$ we herein report the synthesis and inhibitory evaluation of nine 2,4-diphenylquinolines, among them five phthalonitrilequinoline dyads (compounds which combine the structural features of quinoline and phthalonitrile nucleus) as CatK inhibitors.

\section{Experimental}

\section{Synthesis}

Procedure for the synthesis of 2,4-diphenylquinolines $\mathbf{4 a}$, 4h and $4 \mathbf{i}$

2,4-Diphenylquinolines $\mathbf{4 a}, \mathbf{4 h}$ and $\mathbf{4 i}$ were prepared following a reported procedure ${ }^{31}$ for other quinolines with some slight modifications.

\section{2,4-Diphenylquinoline (4a) ${ }^{31}$}

Aniline (1a) $(0.48 \mathrm{~mL}, 5.25 \mathrm{mmol})$, benzaldehyde (2a) $(0.51 \mathrm{~mL}, 5 \mathrm{mmol})$, phenylacetylene (3a) $(0.84 \mathrm{~mL}$, $7.5 \mathrm{mmol}), \mathrm{FeCl}_{3}(81.1 \mathrm{mg}, 0.5 \mathrm{mmol}, 10 \mathrm{~mol} \%)$, and toluene $(5 \mathrm{~mL})$ were sequentially added to a $10-\mathrm{mL}$ round-bottom flask under an air atmosphere. The flask was connected to a reflux condenser and the resulting mixture was stirred at $110{ }^{\circ} \mathrm{C}$ for $24 \mathrm{~h}$. After cooling to room temperature (r.t.), the reaction mixture was filtered through a short silica gel plug using $\mathrm{CH}_{2} \mathrm{Cl}_{2}$ as eluent. The filtrate was dried over $\mathrm{Na}_{2} \mathrm{SO}_{4}$, filtered, and the solvent concentrated under vacuum. The product was chromatographed over silica gel (70-230 mesh) and eluted with hexane/ethyl acetate (EtOAc) $(9.5: 0.5, \mathrm{v} / \mathrm{v})$. After solvent removal, the solid was recrystallized from ethanol to give the product in $74 \%$ yield $(1.04 \mathrm{~g}, 3.7 \mathrm{mmol})$. Data for 4a: mp $110-11{ }^{\circ} \mathrm{C}$; ${ }^{1} \mathrm{H}$ nuclear magnetic resonance (NMR) (400.15 MHz, $\left.\mathrm{CDCl}_{3}\right) \delta 8.26(\mathrm{dd}, J 8.5,0.5 \mathrm{~Hz}$, $1 \mathrm{H}), 8.23-8.18(\mathrm{~m}, 2 \mathrm{H}), 7.91(\mathrm{dd}, J 8.4,0.8 \mathrm{~Hz}, 1 \mathrm{H})$, 7.83 (s, 1H), 7.74 (ddd, $J 8.4,6.8,1.4 \mathrm{~Hz}, 1 \mathrm{H}), 7.61$ $7.44(\mathrm{~m}, 9 \mathrm{H}) ;{ }^{13} \mathrm{C}$ NMR $\left(100.62 \mathrm{MHz}, \mathrm{CDCl}_{3}\right) \delta 157.1$, 149.3, 149.0, 139.8, 138.6, 130.3, 129.7, 129.6, 129.5, 129.0, 128.7, 128.5, 127.7, 126.5, 125.9, 125.8, 119.5; ${ }^{13} \mathrm{C}$ distortionless enhancement by polarization transfer (DEPT)-135 NMR (100.62 MHz, $\left.\mathrm{CDCl}_{3}\right) \delta 130.3,129.7$, 129.6, 129.5, 129.0, 128.7, 128.5, 127.7, 126.5, 125.8, 119.5; Fourier transform infrared spectroscopy (FTIR) $(\mathrm{KBr}) \mathrm{v} / \mathrm{cm}^{-1} 3052,1589,1545,1488,1444,1406$, 1356, 1029, 889, 795, 771, 702, 590; high-resolution mass spectrometry (HRMS) (electrospray ionization-time of flight (ESI-TOF)) $\mathrm{m} / z$, calcd. for $\mathrm{C}_{21} \mathrm{H}_{16} \mathrm{~N}[\mathrm{M}+\mathrm{H}]^{+}$: 282.1277; found: 282.1291 .

\section{2-(3,4-Dimethoxyphenyl)-4-phenylquinoline $(\mathbf{4 h})^{32}$}

This compound was prepared following the procedure described for 4a using aniline (1a) $(96 \mu \mathrm{L}, 1.05 \mathrm{mmol})$, 3,4-dimethoxybenzaldehyde (2d) (167.8 $\mathrm{mg}, 1 \mathrm{mmol}$ ), phenylacetylene (3a) $(168 \mu \mathrm{L}, 1.5 \mathrm{mmol}), \mathrm{FeCl}_{3}(16.2 \mathrm{mg}$, $0.1 \mathrm{mmol}, 10 \mathrm{~mol} \%)$, and toluene $(1 \mathrm{~mL})$. The product was chromatographed over silica gel (70-230 mesh) and eluted with hexane/EtOAc $(8: 2, \mathrm{v} / \mathrm{v})$ to give the product in $50 \%$ yield (171 mg, $0.5 \mathrm{mmol})$. Data for $\mathbf{4 h}$ : $\mathrm{mp} 149-151^{\circ} \mathrm{C}$; ${ }^{1} \mathrm{H}$ NMR (400.15 MHz, $\left.\mathrm{CDCl}_{3}\right) \delta$ 8.25-8.20 (m, 1H), 7.91-7.86 (m, 2H), $7.79(\mathrm{~s}, 1 \mathrm{H}), 7.75-7.68(\mathrm{~m}, 2 \mathrm{H})$, 7.60-7.49 (m, 5H), 7.45 (ddd, J 8.3, 6.8, $1.3 \mathrm{~Hz}, 1 \mathrm{H}), 6.99$ (d, J $8.4 \mathrm{~Hz}, 1 \mathrm{H}), 4.06$ (s, 3H), 3.96 (s, 3H); ${ }^{13} \mathrm{C}$ NMR $\left(100.63 \mathrm{MHz}, \mathrm{CDCl}_{3}\right) \delta 156.5,150.5,149.5,149.1,148.8$, 138.6, 132.6, 130.0, 129.7, 129.6, 128.7, 128.5, 126.2, $125.8,125.7,120.4,119.1,111.1,110.5,56.2,56.1$; ${ }^{13} \mathrm{C}$ DEPT-135 NMR (100.63 MHz, $\left.\mathrm{CDCl}_{3}\right) \delta 130.0,129.7$, 129.6, 128.7, 128.5, 126.2, 125.8, 120.4, 119.1, 111.1, 110.5, 56.2, 56.1; FTIR (KBr) v / cm $\mathrm{cm}^{-1} 3059,2993,1589$, 1515, 1427, 1349, 1258, 1169, 1023, 870, 796, 776, 764, 702, 612; HRMS (ESI-TOF) $\mathrm{m} / z$, calcd. for $\mathrm{C}_{23} \mathrm{H}_{20} \mathrm{NO}_{2}$ $[\mathrm{M}+\mathrm{H}]^{+}$: 342.1489; found: 342.1489 .

\section{4-(4-Phenylquinolin-2-yl)phenol (4i) ${ }^{33}$}

This compound was prepared following the procedure described for 4a using aniline (1a) $(192 \mu \mathrm{L}, 2.1 \mathrm{mmol})$, 4-acetoxybenzaldehyde (2e) (328.3 mg, $2 \mathrm{mmol}$ ), phenylacetylene (3a) $(336 \mu \mathrm{L}, 3 \mathrm{mmol}), \mathrm{FeCl}_{3}(32.4 \mathrm{mg}$, $0.2 \mathrm{mmol}, 10 \mathrm{~mol} \%)$, and toluene $(2 \mathrm{~mL})$. The product was chromatographed over silica gel (70-230 mesh) and eluted 
with hexane/EtOAc $(8: 2, \mathrm{v} / \mathrm{v})$ to give the product in $25 \%$ yield (148 mg, $0.5 \mathrm{mmol})$. Data for $4 \mathbf{i}: \mathrm{mp} 195-197^{\circ} \mathrm{C}$; ${ }^{1} \mathrm{H}$ NMR (400.15 MHz, dimethyl sulfoxide (DMSO- $d_{6}$ )) $\delta 9.87(\mathrm{~s}, 1 \mathrm{H}), 8.20(\mathrm{~d}, J 8.7 \mathrm{~Hz}, 2 \mathrm{H}), 8.09$ (dd, $J$ 8.4, $0.5 \mathrm{~Hz}, 1 \mathrm{H}), 7.93(\mathrm{~s}, 1 \mathrm{H}), 7.81(\mathrm{dd}, J 8.4,0.7 \mathrm{~Hz}, 1 \mathrm{H}), 7.76$ (ddd, $J$ 8.3, 6.9, $1.4 \mathrm{~Hz}, 1 \mathrm{H}), 7.65-7.49(\mathrm{~m}, 6 \mathrm{H}), 6.92(\mathrm{~d}$, $J 8.8 \mathrm{~Hz}, 2 \mathrm{H}) ;{ }^{13} \mathrm{C}$ NMR $\left(100.63 \mathrm{MHz}\right.$, DMSO- $\left.d_{6}\right) \delta 159.2$, 155.7, 148.3, 148.1, 137.7, 129.7, 129.5, 129.4, 128.9, $128.7,128.5,126.2,125.2,124.7,118.2,115.6 ;{ }^{13} \mathrm{C}$ DEPT135 NMR (100.63 MHz, DMSO- $\left.d_{6}\right) \delta 129.7,129.5,129.4$, 128.9, 128.7, 128.5, 126.2, 125.2, 118.2, 115.6; FTIR $(\mathrm{KBr}) \mathrm{v} / \mathrm{cm}^{-1} 3400,3058,1589,1547,1491,1356,1229$, $838,769,702,618,547$; HRMS (ESI-TOF) $\mathrm{m} / z$, calcd. for $\mathrm{C}_{21} \mathrm{H}_{16} \mathrm{NO}[\mathrm{M}+\mathrm{H}]^{+}:$298.1226; found: 298.1233 .

Procedure for the synthesis of 4-(4-phenylquinolin-2-yl) benzonitrile $(\mathbf{4 g})^{34}$

The procedure is the same as that we reported previously ${ }^{35}$ for phthalonitrile-quinoline dyads $\mathbf{4 b - 4 f}$. To a $15-\mathrm{mL}$ glass pressure tube, it was sequentially added $p$-chloranil (135.2 $\mathrm{mg}, 0.55 \mathrm{mmol}), \mathrm{NbCl}_{5}(67.5 \mathrm{mg}, 0.25 \mathrm{mmol}$, $50 \mathrm{~mol} \%)$, and anhydrous $\mathrm{CH}_{3} \mathrm{CN}(1 \mathrm{~mL})$ under an argon atmosphere. To this mixture, it was added a previously prepared solution of aniline (1a) $(46 \mu \mathrm{L}, 0.5 \mathrm{mmol})$, 4-cyanobenzaldehyde (2c) $(0.5 \mathrm{mmol})$, and phenylacetylene (3a) $(61 \mu \mathrm{L}, 0.55 \mathrm{mmol})$ in $4 \mathrm{~mL}$ of $\mathrm{CH}_{3} \mathrm{CN}$ under argon atmosphere. The glass tube was closed, and the resulting mixture was stirred at $100{ }^{\circ} \mathrm{C}$ for $24 \mathrm{~h}$. After cooling to r.t., the reaction mixture was quenched with $\mathrm{H}_{2} \mathrm{O}(5 \mathrm{~mL})$ and extracted with $\mathrm{CH}_{2} \mathrm{Cl}_{2}(3 \times 20 \mathrm{~mL})$. The organic extracts were washed with saturated aqueous $\mathrm{NaHCO}_{3}(3 \times 20 \mathrm{~mL})$ and $\mathrm{H}_{2} \mathrm{O}(3 \times 50 \mathrm{~mL})$, dried over $\mathrm{Na}_{2} \mathrm{SO}_{4}$, filtered, and the solvent concentrated under vacuum. The product was chromatographed over silica gel (70-230 mesh) and eluted with $\mathrm{CH}_{2} \mathrm{Cl}_{2} /$ hexane $(9: 1$, v/v). After solvent removal, the solid was sonicated with ethanol $(10 \mathrm{~mL})$ for $20 \mathrm{~min}$, followed by cooling in a refrigerator overnight, filtration, and dried under vacuum to give the product in $49 \%$ yield (75.2 $\mathrm{mg}, 0.245 \mathrm{mmol})$. Data for $\mathbf{4 g}$ : $\mathrm{mp} 175-177{ }^{\circ} \mathrm{C}$; ${ }^{1} \mathrm{H}$ NMR $\left(400.15 \mathrm{MHz}, \mathrm{CDCl}_{3}\right) \delta 8.33(\mathrm{~d}, J 8.6 \mathrm{~Hz}, 2 \mathrm{H})$, $8.25(\mathrm{dd}, J 8.5,0.5 \mathrm{~Hz}, 1 \mathrm{H}), 7.94(\mathrm{dd}, J 8.4,0.8 \mathrm{~Hz}$, $1 \mathrm{H}), 7.84-7.75(\mathrm{~m}, 4 \mathrm{H}), 7.59-7.51(\mathrm{~m}, 6 \mathrm{H}) ;{ }^{13} \mathrm{C} \mathrm{NMR}$ $\left(100.63 \mathrm{MHz}, \mathrm{CDCl}_{3}\right) \delta 154.6,149.9,148.9,143.9,138.1$, $132.7,130.4,130.1,129.6,128.9,128.8,128.2,127.3$, 126.3, 125.9, 119.1, 119.0, 112.9; ${ }^{13} \mathrm{C}$ DEPT-135 NMR $\left(100.63 \mathrm{MHz}, \mathrm{CDCl}_{3}\right) \delta 132.7,130.4,130.1,129.6,128.9$, 128.8, 128.2, 127.3, 125.9, 119.1; FTIR (KBr) v / cm ${ }^{-1}$ 3057, 3036, 2221, 1589, 1542, 1491, 1417, 1384, 1356, 844, 766, 701, 555; HRMS (ESI-TOF) $\mathrm{m} / \mathrm{z}$, calcd. for $\mathrm{C}_{22} \mathrm{H}_{15} \mathrm{~N}_{2}[\mathrm{M}+\mathrm{H}]^{+}$: 307.1230; found: 307.1232.

\section{Expression and purification of cathepsin $\mathrm{K}$}

Recombinant human cathepsins $\mathrm{K}$ was obtained by expression in Pichia pastoris system and purified as previously described. ${ }^{36,37}$ The molar concentrations of enzyme were determined by active site titration using E-64, following the conditions previously described. ${ }^{38}$

\section{Kinetic measurements}

The enzyme activities were measured by cleavage of the fluorogenic Z-Phe-Arg-4-methyl-coumaryl7-amide (Z-Phe-Arg-MCA) substrate releasing 7-amino-4-methylcoumarin (AMC) which is detected in the fluorimeter (Luminescence Spectrometer LS 50B, PerkinElmer) at excitation and emission wavelengths of 380 and $460 \mathrm{~nm}$, respectively. The protease inhibitory activity was performed in cuvette and the final volume of reaction was $1000 \mu \mathrm{L}$. All the assays were performed at $25{ }^{\circ} \mathrm{C}$ temperature in $100 \mathrm{mM}$ sodium acetate buffer (pH 5.5, containing $2.5 \mathrm{mM}$ dithiothreitol (DTT) and $2.5 \mathrm{mM}$ ethylenediaminetetraacetic acid (EDTA)). Each inhibitor was solubilized in dimethyl sulfoxide and $5 \mu \mathrm{L}$ of this solution were added prior to the measurement of enzyme activity and the assays were performed at a fixed enzyme concentration $(2 \mathrm{nM})$ and substrate concentration $(10 \mu \mathrm{M})$.

In the assay, the compounds to be tested were incubated with enzyme in buffer for $5 \mathrm{~min}$. After the incubation the fluorogenic substrate was added and the fluorescence reading was performed for $5 \mathrm{~min}$. Experiments were performed in triplicate and a positive control (irreversible inhibitor, E-64) and a negative control (without inhibitor) were used. The percentage of inhibition was calculated according to the equation: inhibition $(\%)=100 \times\left(1-\mathrm{V}_{\mathrm{i}} / \mathrm{V}_{0}\right)$, where $\mathrm{V}_{\mathrm{i}}$ and $\mathrm{V}_{0}$ are initial velocities (enzyme activities) determined in the presence or absence of inhibitor, respectively. Values of half-maximal inhibitory concentration $\left(\mathrm{IC}_{50}\right)$ were determined by making rate measurements for at least seven inhibitor concentrations. To determine the mechanism of inhibition and inhibition constant $\left(\mathrm{K}_{\mathrm{i}}\right)$ value, compound $\mathbf{4 b}$ was tested under the same experimental conditions for three different inhibitor concentrations (with concentrations ranging from 1 to $5 \mu \mathrm{M})$ and five concentrations of Z-Phe-Arg-MCA (concentrations ranging between 1.25 and $20 \mu \mathrm{M}$ ) and were determined through visual representation of inhibition mechanism using Lineweaver-Burk and Dixon plot analysis. All kinetic parameters were analyzed using the SigmaPlot $12.0^{39}$ enzyme kinetics module. The values represent means of at least three individual experiments. 


\section{Molecular modeling}

The molecular docking simulations were performed in Rosetta software version $3.8^{40}$ using the RosettaScripts application. ${ }^{41}$ First, the crystal structure of cathepsin $\mathrm{K}$ (CatK; Protein Data Bank (PDB) 1ATK) was subjected to an energy minimization using the Rosetta Fast Relax protocol with a knowledge-based all-atom energy function, which consists of five cycles with rotamer repacking and minimization where the repulsive weight in the scoring function slowly ramps up from a very low value to the normal value from one round to the next, allowing to find low-energy backbone and side-chain conformations near a starting conformation. ${ }^{42,43}$ A three-dimensional conformer library for the $\mathbf{4 b}$ ligand was generated using the BCL::Conf, ${ }^{44}$ by providing ligand in the SDF format. The initial geometric center of the ligand in the CatK-4b complex was predicted using PatchDock server. ${ }^{45}$ Beginning from the initial ligand pose, 10000 cycles of sampling were performed in the Monte Carlo simulation and the best scoring ligand pose was kept. A total of 1000 models was generated using the routines described by Combs et al. ${ }^{46}$ The final model was selected from the set of generated models by filtering the top 50 models, sorted by Rosetta energy function, a proxy for the free energy which consists of a combination of physics-based and statistics-based potentials. ${ }^{46}$ Finally, the subset of models was grouped based on their structural similarity, given by the mean square root deviation (RMSD), and the one with the lowest average RMSD to all other structures was chosen as a representative model.

\section{Results and Discussion}

Synthesis of 2,4-diphenylquinolines and phthalonitrilequinoline dyads

The synthesis of 2,4-diphenylquinolines (4a and $\mathbf{4 g - 4 i}$ ) and phthalonitrile-quinoline dyads (4b-4f) was carried out by a multicomponent reaction involving benzaldehydes ( $2 \mathbf{a}$ and 2c-2e) (or 4-formylphthalonitrile, 2b), anilines (1a-1d) and phenylacetylenes (3a and $\mathbf{3 b}$ ) in the presence of a Lewis acid $\left(\mathrm{FeCl}_{3}\right.$ or $\left.\mathrm{NbCl}_{5}\right)$ and an oxidant agent ( $p$-chloranil or $\mathrm{O}_{2}$ from air) (Table 1). ${ }^{31,35}$

Table 1. Synthesis of 2,4-diphenylquinolines and phthalonitrile-quinoline dyads

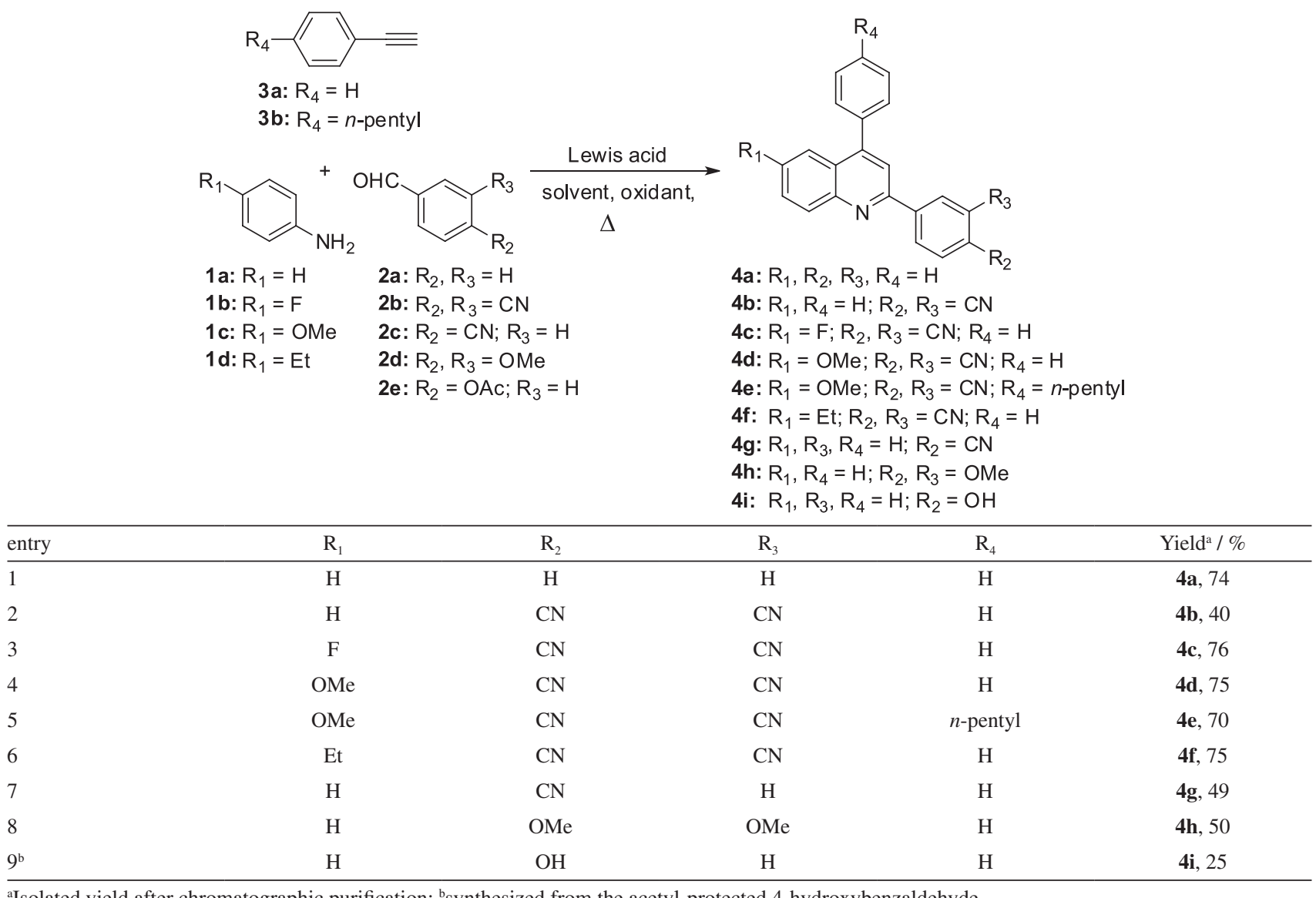

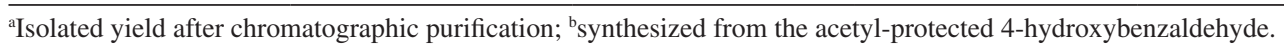


Due to the incompatibility of phenol group with this multicomponent reaction, the quinoline $4 \mathbf{i}$ was synthesized from the acetyl-protected 4-hydroxybenzaldehyde (2e). The deprotection of acetyl group occurred in situ and produced quinoline $4 \mathbf{i}$ in $25 \%$ yield (Table 1, entry 9).

Detailed information on the synthesis and characterization ( ${ }^{1} \mathrm{H}$ NMR, ${ }^{13} \mathrm{C}$ NMR, HRMS, IR, mp) of the phthalonitrile-quinoline dyads $\mathbf{4 b}-\mathbf{4 f}$ (Table 1 , entries 2-6) is provided in literature. ${ }^{35}$

\section{Evaluation of CatK inhibitory activities of synthetic compounds}

Nine compounds were tested as CatK inhibitors. Before checking their inhibitory activity, we have evaluated intrinsic fluorescence of the compounds which could lead to false positives. None of the compounds exhibited intrinsic fluorescence.

An initial screening was performed to check the ability of the compounds in significantly interfering with the catalytic activity of the enzyme. They were initially tested at $50 \mu \mathrm{M}$ concentration. In this concentration most of compounds showed $100 \%$ of inhibition of the CatK catalytic activity. Subsequently, the $\mathrm{IC}_{50}$ values were determined. Results are shown in Table 2.

The evaluated compounds showed significant inhibitory activity with $\mathrm{IC}_{50}$ values ranging from 7.29 to $1.41 \mu \mathrm{M}$. Compounds $\mathbf{4 a}, \mathbf{4 g}$ and $\mathbf{4 b}$ displayed $\mathrm{IC}_{50}$ of 7.29, 3.91 and $1.55 \mu \mathrm{M}$, respectively. The analysis of their structures allowed to suggest the importance of $\mathrm{CN}$ groups as $\mathrm{R}_{2}$ and $\mathrm{R}_{3}$. The presence of a $\mathrm{CN}$ group at $\mathrm{C}^{\prime}$, in $\mathbf{4 g}$, reduced the $\mathrm{IC}_{50}$ value by half. When a second $\mathrm{CN}$ group has been inserted at $\mathrm{C} 3$ ' the compound $\mathbf{4 b}$ had a considerable decrease in the $\mathrm{IC}_{50}$ compared to the activity of compound $\mathbf{4 a}$. When $\mathrm{CN}$ groups were replaced by other substituents there was a decrease in the inhibitory activity of the compounds as observed for $\mathbf{4 h}$ and $\mathbf{4 i}$, which presented $\mathrm{IC}_{50}$ of 6.71 and $6.54 \mu \mathrm{M}$, respectively.

When the substituents were linked to C6 and C4" positions the resulting compound did not significantly

Table 2. Structures of quinolines and values of $\mathrm{IC}_{50}$ on CatK

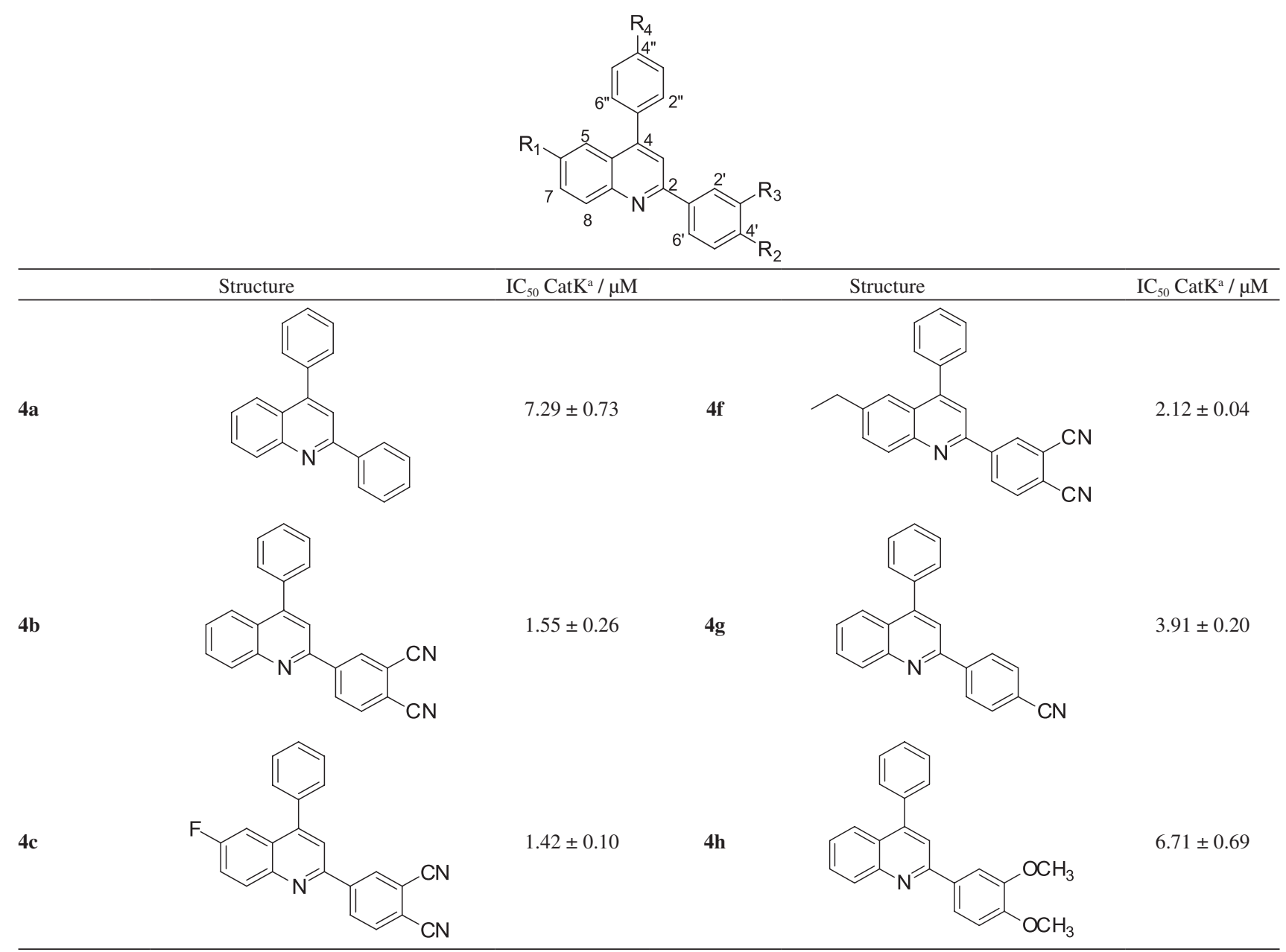


Table 2. Structures of quinolines and values of $\mathrm{IC}_{50}$ on CatK (cont.)

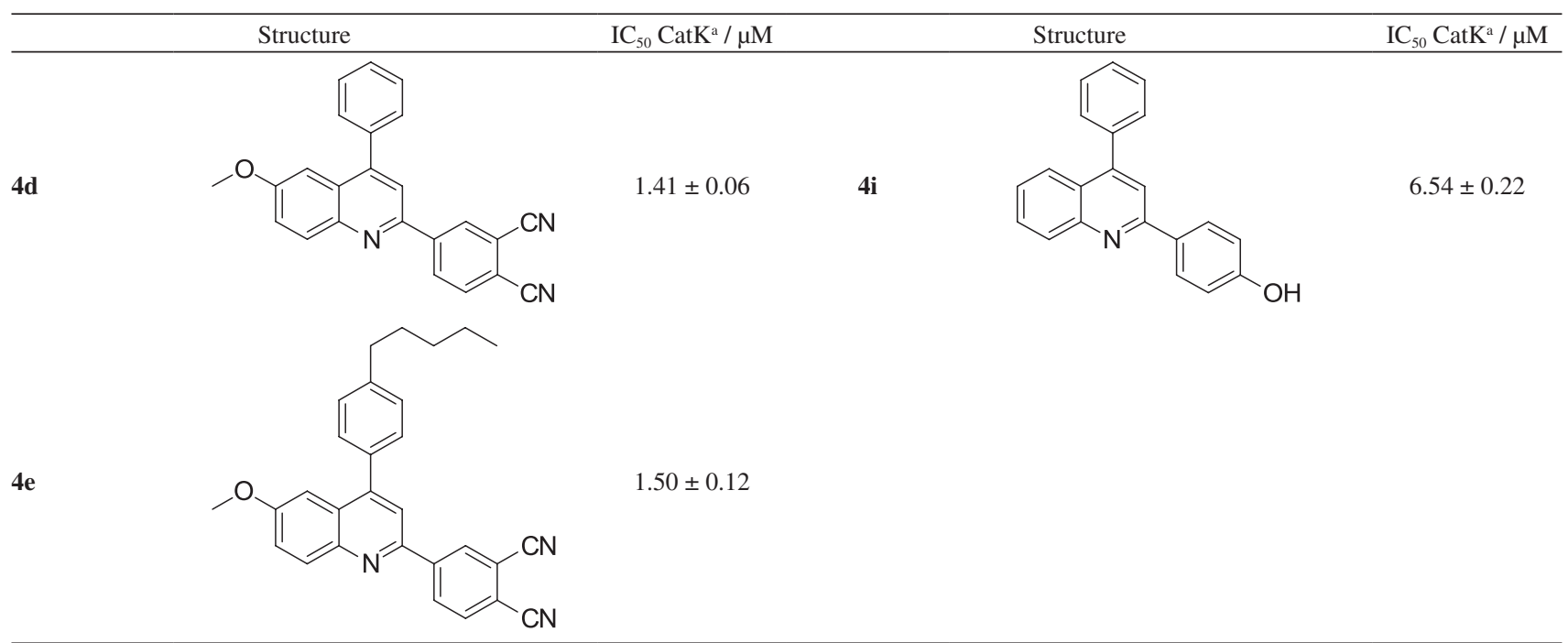

${ }^{a}$ The values represent means of three individual experiments $\pm \mathrm{SD}$. $\mathrm{IC}_{50}$ : half-maximal inhibitory concentration; CatK: cathepsin $\mathrm{K}$.

change the inhibitory activity, as observed for compounds $\mathbf{4 c}$, $\mathbf{4 d}, \mathbf{4 e}$ and $\mathbf{4 f}$ which exhibited $\mathrm{IC}_{50}$ of $1.42,1.41,1.50$ and $2.12 \mu \mathrm{M}$, respectively.

\section{Mechanism of inhibition and $\mathrm{K}_{\mathrm{i}}$ value}

Based on $\mathrm{IC}_{50}$ values and chemical structures, compound $\mathbf{4 b}$ was selected as representative for determining the type of inhibition and $\mathrm{K}_{\mathrm{i}}$ value of this class of compounds. The mechanism of action was determined using the Lineweaver-Burk double-reciprocal plot method and also the Dixon graphs.

Compound $\mathbf{4 b}$ showed uncompetitive inhibition, i.e., it binds exclusively to the enzyme-substrate (ES) complex.

(a)

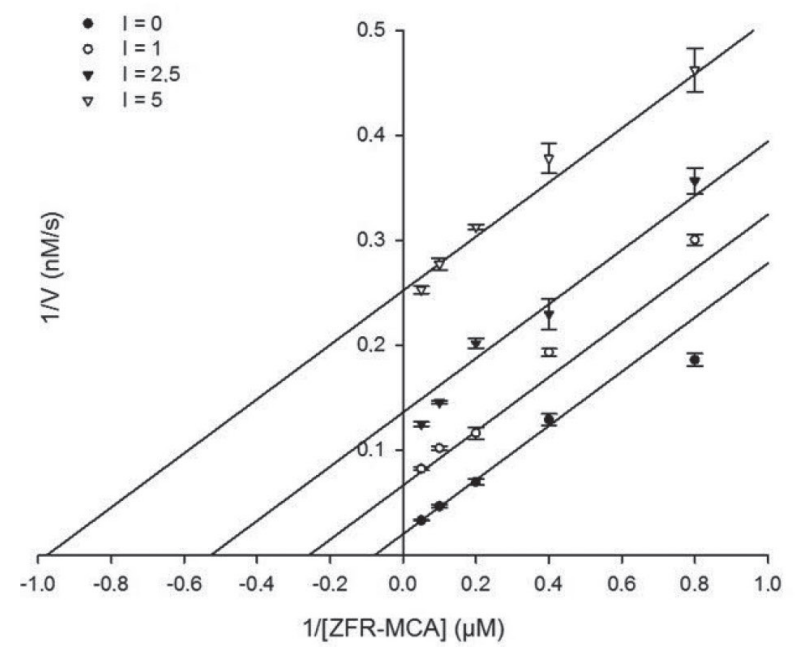

The prior formation of the ES complex is necessary for the inhibitor to bind and inhibit the enzymatic activity. Thus, in this type of inhibition, a decrease in the apparent values of $\mathrm{V}_{\max }$ (maximum velocity) and $\mathrm{K}_{\mathrm{m}}$ (Michaelis constant) occurs with the increase of inhibitor concentration. ${ }^{47}$ For this type of inhibition, the graphs plotted have parallel lines between them (Figure 1).

The determination of the affinity of the inhibitor by the enzyme is of great interest in the process of searching for enzymatic inhibitors. This affinity is defined by the $\mathrm{K}_{\mathrm{i}}$ value and can be determined by kinetic data obtained in specific experiments to determine the mechanism of action of the inhibitors. The same data of Figure 1 was employed to determine the $\mathrm{K}_{\mathrm{i}}$ values of the uncompetitive inhibitor.

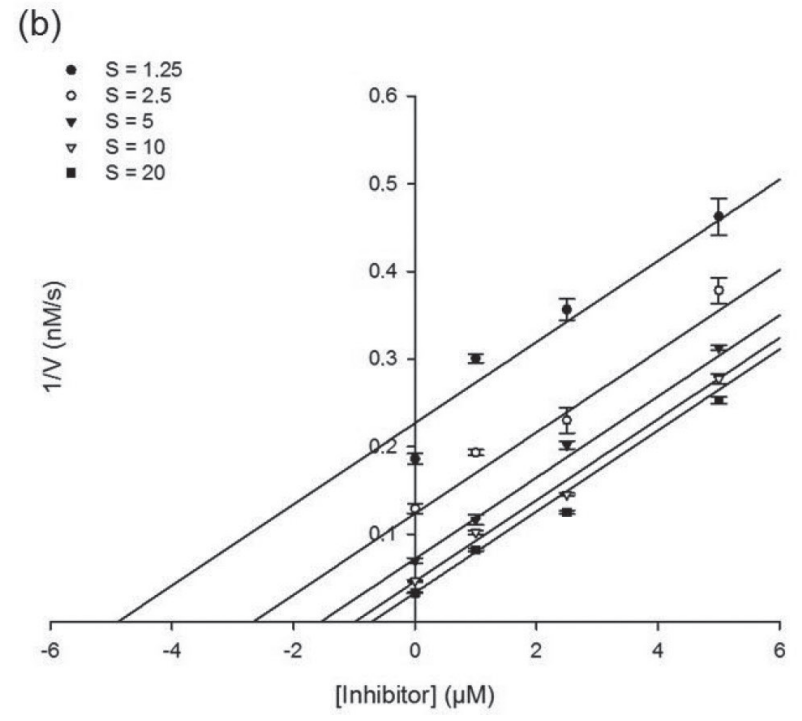

Figure 1. Uncompetitive inhibition profile of compound $\mathbf{4 b}$. (a) Lineweaver-Burk plot; (B) Dixon plots. All data points are means of three experiments \pm SD. 
The $\mathrm{K}_{\mathrm{i}}$ value for $\mathbf{4 b}$ was $0.4 \mu \mathrm{M}$ thus confirming that the evaluated quinolinic derivative can be considered as a new potential lead of uncompetitive inhibitors of CatK with affinity values in a sub- $\mu \mathrm{M}$ range.

\section{Docking}

According to the molecular docking simulation, compound $\mathbf{4 b}$ binds to an exosite of CatK and not to the catalytic site of the enzyme, as shown in Figure 2. This result is in agreement with the experimental data obtained in the study of mechanism of action, where $\mathbf{4 b}$ presented an uncompetitive inhibition mode, showing no competition with the substrate for the enzyme's active site.

Hydrogen bonding and hydrophobic interactions between ligand molecule and amino acid residue side

(a)

\section{Predicted binding mode of $4 \mathrm{~b}$ within CatK}

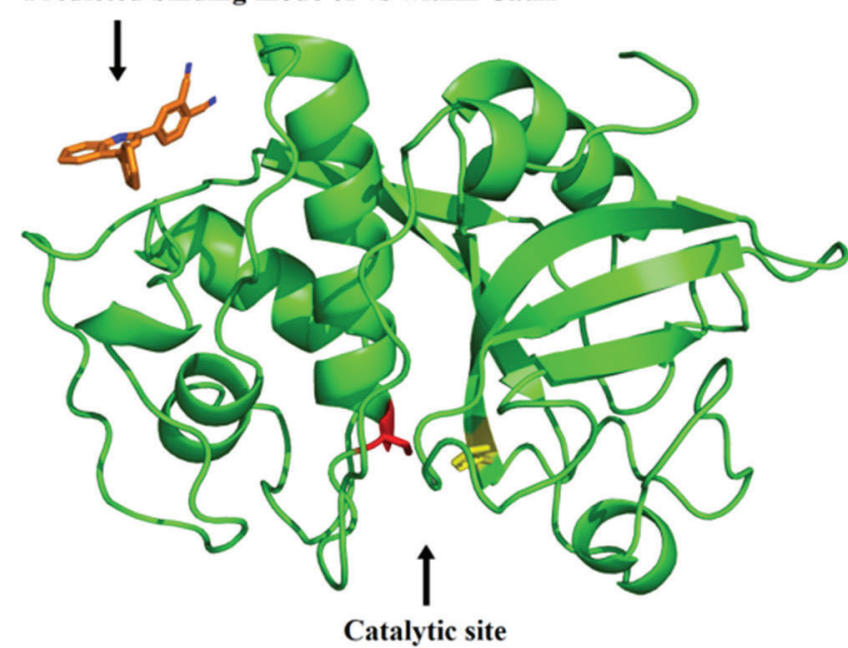

chains are the major forces responsible for stabilizing energetically-favored ligands at the interface of the protein structure. ${ }^{48,49}$ In the predicted binding mode, Lys 41 residue is oriented towards two $\mathrm{CN}$ groups on the inhibitor molecule at a distance of about $2.4 \AA$ (Figure 3a). Thus, formation of a hydrogen bond involving the $\varepsilon$-amino group of the Lys 41 and the $\mathrm{CN}$ groups of the inhibitor may occur. Similarly, Arg 108 also interacts with one of the CN groups through hydrogen bonding at a Euclidean distance of $2.9 \AA$. In addition to interactions with the $\mathrm{CN}$ groups, it was also possible to observe that Lys103 is positioned so that a hydrogen bond between its terminal amino group and the nitrogen of quinoline ring may occur. These results are in good agreement with the experimental data, demonstrating the importance of the $\mathrm{CN}$ groups for the activity of the evaluated compounds. For compound $\mathbf{4 h}$ with

(b)

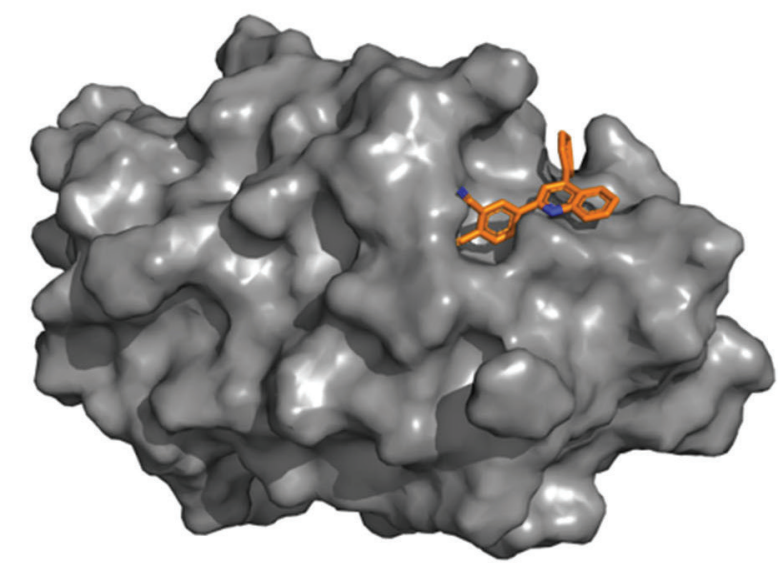

Figure 2. (a) Predicted binding mode of compound 4b within CatK. C25 and H162 from the catalytic triad are shown in red and yellow, respectively; (b) solvent-accessible surface representation of CatK-4b complex.

(a)

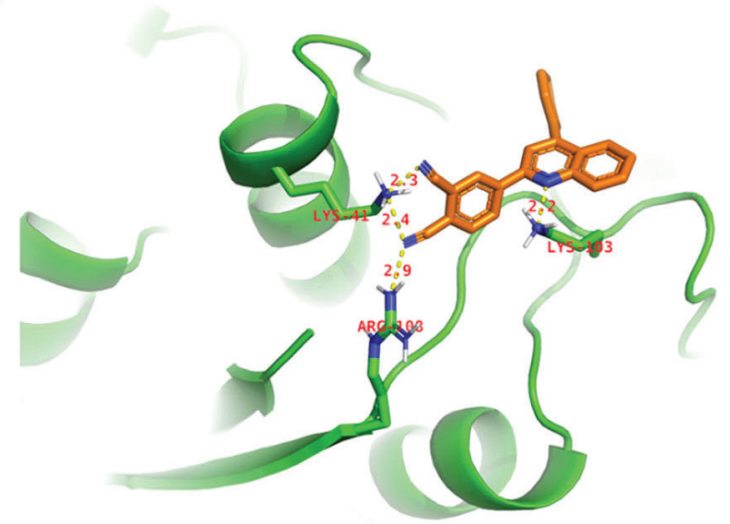

(b)

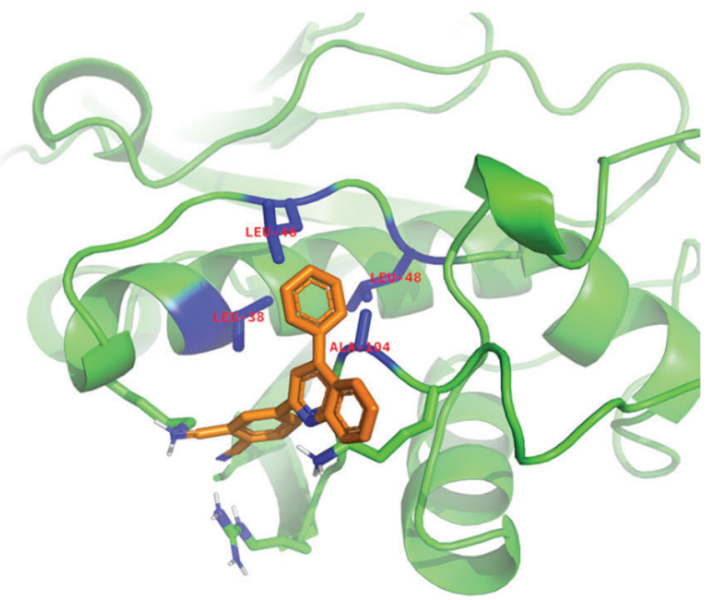

Figure 3. Predicting interactions between compound $\mathbf{4 b}$ and CatK. (a) Hydrogen bonding interactions between $\mathrm{CN}$ groups and nitrogen of quinoline ring with CatK; (b) hydrophobic pocket formed by Leu38, Leu46, Leu48 and Ala104 which accommodates the $\mathbf{4 b}$ phenyl ring. 
two methoxyl groups $\left(\mathrm{OCH}_{3}\right)$ replacing the $\mathrm{CN}$ groups, the $\mathrm{IC}_{50}$ value is higher due to possible steric hindrance by the $\mathrm{CH}_{3}$ groups which are relatively bulky and make hydrogen bonding interactions with Lys41 and Arg 108 less effective. Concerning compound $\mathbf{4 i}$, no steric hindrance occurs, however, the $\mathrm{IC}_{50}$ value is increased by replacing the $\mathrm{CN}$ groups for $\mathrm{OH}$, because the hydrogen bonding is stronger with the $\mathrm{CN}$ group than with the $\mathrm{OH}$, as calculated by Chen et al..${ }^{50}$ who described that $\mathrm{CN}$ group has a hydrogen bonding capacity of about two times greater than $\mathrm{OH}$ groups in some biological media.

In addition, important hydrophobic interactions are also observed between compound $\mathbf{4 b}$ and CatK. As shown in Figure $3 b$, the phenyl group is oriented towards a hydrophobic pocket of the protein formed by Leu38, Leu46, Leu48, and Ala104 residues.

\section{Conclusions}

Herein, we described the synthesis of nine 2,4-diphenylquinolines among them five phthalonitrilequinoline dyads employing a multicomponent reaction approach (MCR). Alternate synthesized 2,4-diphenylquinolines were screened to evaluate their inhibitory capacity against CatK. The analysis revealed the importance of the $\mathrm{CN}$ groups attached to the quinolines evaluated for inhibitory activity of this enzyme. Inhibition mechanism studies have shown uncompetitive inhibition and molecular docking was in agreement with the obtained experimental results and revealed favorable interactions between the protein and the evaluated inhibitor. In addition, it was possible to confirm that the inhibitor does not bind to the catalytic site of the enzyme, which is in accordance to the inhibition mode obtained experimentally.

\section{Supplementary Information}

Supplementary information is available free of charge at http://jbcs.sbq.org.br as PDF file.

\section{Acknowledgments}

T. L. S. acknowledges a sandwich scholarship from CAPES (proc. PDSE-88881.134061/2016-01). This study was supported by the State of São Paulo Research Foundation (FAPESP, proc. 2012/11819-8, 2014/24506-3, 2017/15455-4 and 2018/00106-7) and Coordination for the Improvement of Higher Education Personnel (CAPES, finance code 001) and by the Canadian Institutes of Health Research (MOP-89974; D. B.).

\section{Author Contributions}

Taynara L. Silva expressed and purified CatK, performed and analyzed all inhibitor kinetic measurements and wrote the first draft of the paper; Aloisio de A. Bartolomeu synthesized the evaluated quinolines, performed all the experiments to determine their structures and their purity and contributed to manuscript writing; Hugo R. de Jesus performed the molecular docking experiments and contributed to manuscript writing; Kleber T. de Oliveira contributed with laboratory and financial structure for the development of the experiments and to manuscript writing; João B. Fernandes contributed with laboratory and financial structure for the development of the experiments; Dieter Brömme contributed with laboratory and financial structure for the development of the experiments and to manuscript writing; Paulo C. Vieira contributed with laboratory and financial structure for the development of the experiments and wrote the final version of the paper.

\section{References}

1. Abdel-Magid, A. F.; ACS Med. Chem. Lett. 2015, 6, 628.

2. Parfitt, A. M.; Miner. Electrolyte Metab. 1980, 4, 273.

3. Drake, M. T.; Clarke, B. L.; Oursler, M. J.; Khosla, S.; Endocr. Rev. 2017, 38, 325.

4. Eriksen, E. F.; Endocr. Rev. 1986, 7, 379.

5. Brömme, D.; Lecaille, F.; Expert Opin. Invest. Drugs 2009, 18, 585.

6. Bonnet, N.; Brun, J.; Rousseau, J.-C.; Duong, L. T.; Ferrari, S. L.; J. Bone Miner. Res. 2017, 32, 1432.

7. Lecaille, F.; Kaleta, J.; Brömme, D.; Chem. Rev. 2002, 102, 4459.

8. Patel, S.; Homaei, A.; El-Seedi, H. R.; Akhtar, N.; Biomed. Pharmacother. 2018, 105, 526.

9. Palermo, C.; Joyce, J. A.; Trends Pharmacol. Sci. 2008, $29,22$.

10. Yasuda, Y.; Kaleta, J.; Brömme, D.; Adv. Drug Delivery Rev. 2005, 57, 973.

11. Stoch, S. A.; Zajic, S.; Stone, J. A.; Miller, D. L.; van Bortel, L.; Lasseter, K. C.; Pramanik, B.; Cilissen, C.; Liu, Q.; Liu, L.; Scott, B. B.; Panebianco, D.; Ding, Y.; Gottesdiener, K.; Wagner, J. A.; Br. J. Clin. Pharmacol. 2013, 75, 1240.

12. Boonen, S.; Rosenberg, E.; Claessens, F.; Vanderschueren, D.; Papapoulos, S.; Curr. Osteoporosis Rep. 2012, 10, 73.

13. Kafienah, W.; Brömme, D.; Buttle, D. J.; Croucher, L. J.; Hollander, A. P.; Biochem. J. 1998, 331, 727.

14. Lecaille, F.; Brömme, D.; Lalmanach, G.; Biochimie 2008, 90 , 208.

15. Dossetter, A. G.; Beeley, H.; Bowyer, J.; Cook, C. R.; Crawford, J. J.; Finlayson, J. E.; Heron, N. M.; Heyes, C.; Highton, A. J.; Hudson, J. A.; Jestel, A.; Kenny, P. W.; Krapp, S.; Martin, 
S.; MacFaul, P. A.; McGuire, T. M.; Gutierrez, P. M.; Morley, A. D.; Morris, J. J.; Page, K. M.; Ribeiro, L. R.; Sawney, H.; Steinbacher, S.; Smith, C.; Vickers, M.; J. Med. Chem. 2012, $55,6363$.

16. Lu, J.; Wang, M.; Wang, Z.; Fu, Z.; Lu, A.; Zhang, G.; J. Enzyme Inhib. Med. Chem. 2018, 33, 890.

17. Petek, N.; Štefane, B.; Novinec, M.; Svete, J.; Bioorg. Chem. 2019, 84, 226.

18. Yuan, X.; Ren, Z.; Wu, Y.; Bougault, C.; Brizuela, L.; Magne, D.; Buchet, R.; Mebarek, S.; Bioorg. Med. Chem. 2019, 27, 1034.

19. Marques, E. F.; Bueno, M. A.; Duarte, P. D.; Silva, L. R. S. P.; Martinelli, A. M.; dos Santos, C. Y.; Severino, R. P.; Brömme, D.; Vieira, P. C.; Corrêa, A. G.; Eur. J. Med. Chem. 2012, 54, 10.

20. Marella, A.; Tanwar, O. P.; Saha, R.; Ali, M. R.; Srivastava, S.; Akhter, M.; Shaquiquzzaman, M.; Alam, M. M.; Saudi Pharm. J. 2013, 21, 1 .

21. Michael, J. P.; Nat. Prod. Rep. 2003, 20, 476.

22. Shang, X.-F.; Morris-Natschke, S. L.; Yang, G.-Z.; Liu, Y.-Q.; Guo, X.; Xu, X.-S.; Goto, M.; Li, J.-C.; Zhang, J.-Y.; Lee, K.-H.; Med. Res. Rev. 2018, 38, 775.

23. Solomon, V. R.; Lee, H.; Curr. Med. Chem. 2011, 18, 1488.

24. Kumar, S.; Bawa, S.; Gupta, H.; Mini-Rev. Med. Chem. 2009, 9, 1648.

25. Alvim Jr., J.; Severino, R. P.; Marques, E. F.; Martinelli, A. M.; Vieira, P. C.; Fernandes, J. B.; da Silva, M. F. G. F.; Corrêa, A. G.; J. Comb. Chem. 2010, 12, 687.

26. Ramalho, S. D.; de Sousa, L. R. F.; Nebo, L.; Maganhi, S. H.; Caracelli, I.; Zukerman-Schpector, J.; Lima, M. I. S.; Alves, M. F. M.; da Silva, M. F. G. F.; Fernandes, J. B.; Vieira, P. C.; Chem. Biodiversity 2014, 11, 1354.

27. Ramalho, S. D.; de Sousa, L. R. F.; Burguer, M. C. M.; Lima, M. I. S.; da Silva, M. F. G. F.; Fernandes, J. B.; Vieira, P. C.; Nat. Prod. Res. 2015, 29, 2212.

28. dos Santos, D. A.; Deobald, A. M.; Cornelio, V. E.; Ávila, R. M. D.; Cornea, R. C.; Bernasconi, G. C. R.; Paixão, M. W.; Vieira, P. C.; Corrêa, A. G.; Bioorg. Med. Chem. 2017, 25, 4620.

29. Sarria, A. L. F.; Silva, T. L.; de Oliveira, J. M.; de Oliveira, M. A. R.; Fernandes, J. B.; da Silva, M. F. G. F.; Vieira, P. C.; Venancio, T.; Alves Filho, E. G.; Batista Jr., J. M.; Guido, R. V. C.; Phytochemistry 2018, 154, 31.

30. Severino, R. P.; Guido, R. C.; Marques, E. F.; Brömme, D.; da Silva, M. F. G. F.; Fernandes, J. B.; Andricopulo, A. D.; Vieira, P. C.; Bioorg. Med. Chem. 2011, 19, 1477.

31. Cao, K.; Zhang, F.; Tu, Y.-Q.; Zhuo, X.-T.; Fan, C.-A.; Chem. Eur. J. 2009, 15, 6332.
32. Mastalir, M.; Glatz, M.; Pittenauer, E.; Allmaier, G.; Kirchner, K.; J. Am. Chem. Soc. 2016, 138, 15543.

33. Enugala, R.; Nuvvula, S.; Kotra, V.; Varala, R.; Adapa, S. R.; Heterocycles 2008, 75, 2523.

34. Kulkarni, A.; Török, B.; Green Chem. 2010, 12, 875.

35. Bartolomeu, A. A.; Brocksom, T. J.; Filho, L. C. S.; de Oliveira, K. T.; Dyes Pigm. 2018, 151, 391.

36. Brömme, D.; Okamoto, K.; Biol. Chem. Hoppe-Seyler 1995 , $376,379$.

37. Linnervers, C. J.; McGrath, M. E.; Armstrong, R.; Mistry, F. R.; Barnes, M. G.; Klaus, J. L.; Palmer, J. T.; Kartz, B. A.; Brömme, D.; Protein Sci. 1997, 6, 919.

38. Barret, A. J.; Kembhavi, A. A.; Brown, M. A.; Kirschke, H.; Knight, C. G.; Tamait, M.; Hanadat, K.; Biochem. J. 1982, 201, 189.

39. SigmaPlot 12.0; Systat Software: San Jose, CA, 2012.

40. Alford, R. F.; Leaver-Fay, A.; Jeliazkov, J. R.; O’Meara, M. J.; DiMaio, F. P.; Park, H.; Shapovalov, M. V.; Renfrew, P. D.; Mulligan, V. K.; Kappel, K.; Labonte, J. W.; Pacella, M. S.; Bonneau, R.; Bradley, P.; Dunbrack Jr., R. L.; Das, R.; Baker, D.; Kuhlman, B.; Kortemme, T.; Gray, J. J.; J. Chem. Theory Comput. 2017, 13, 3031.

41. Fleshman, S. J.; Leaver-Fay, A.; Corn, J. E.; Strauch, E. M.; Khare, S. D.; Koga, N.; Ashworth, J.; Murphy, P.; Richter, F.; Lemmon, G.; Meiler, J.; Baker, D.; PLoS One 2011, 6, DOI 10.1371/journal.pone.0020161.

42. Nivón, L. G.; Moretti, R.; Baker, D.; PLoS One 2013, 8, DOI 10.1371/journal.pone.0059004.

43. Conway, P.; Tyka, M. D.; DiMaio, F.; Konerding, D. E.; Baker, D.; Protein Sci. 2014, 23, 47.

44. Kothiwale, S.; Mendenhall, J. L.; Meiler, J.; J. Cheminform. 2015, 7, DOI 10.1186/s13321-015-0095-1.

45. Schneidman-Duhovny, D.; Inbar, Y.; Nussinov, R.; Wolfson, H. J.; Nucleic Acids Res. 2005, 33, 363.

46. Combs, S. A.; DeLuca, S. L.; DeLuca, S. H.; Lemmon, G. H.; Nannemann, D. P.; Nguyen, E. D.; Willis, J. R.; Sheehan, J. H.; Meiler, J.; Nat. Protoc. 2013, 8, 1277.

47. Copeland, R. A.; Evaluation of Enzyme Inhibitors in Drug Discovery: A Guide for Medicine Chemists and Pharmacologists, $2^{\text {nd }}$ ed.; Wiley: New Jersey, 2005.

48. Babine, R. E.; Bender, S. L.; Chem. Rev. 1997, 97, 1359.

49. Patil, R.; Das, S.; Stanley, A.; Yadav, L.; Sudhakar, A.; Varma, A. K.; PLoS One 2010, 5, e12029.

50. Chen, D.; Oezguen, N.; Urvil, P.; Ferguson, C.; Dann, S. M.; Savidge, T. C.; Sci. Adv. 2016, 2, DOI 10.1126/sciadv.1501240.

Submitted: October 24, 2019 Published online: March 17, 2020 